\title{
ERRATUM TO: NUTRITIONAL CONCEPTS AND FREQUENCY OF FOODSTUFFS MENTIONED IN THE HOLY QURAN
}

Published online: 23 December 2014

(C) Springer Science+Business Media New York 2014

\section{Erratum to: J Relig Health DOI 10.1007/s10943-014-9855-x}

The original version of this article, published in Journal of Religion and Health, contained a misprint in the list of references. The correct citation of reference "Marwat et al. (2009)" should be "Marwat et al. (2009a, b)" in the text. The exact references are listed below.

\section{References}

Marwat, S. K., Khan, M. A., Khan, M. A., Ahmad, M., Zafar, M., Rehman, F., \& Sultana, S. (2009a). Fruit plant species mentioned in the Holy Qura'n and ahadith and their ethnomedicinal importance. American-Eurasian Journal of Agricultural and Environmental Science, 5(2), 284-295.

Marwat, S. K., Khan, M. A., Khan, M. A., Ahmad, M., Zafar, M., Rehman, F., \& Sultana, S. (2009b). Vegetables mentioned in the Holy Qura'n and Ahadith and their ethnomedicinal studies in Dera Ismail Khan, NWFP, Pakistan. Pakistan Journal of Nutrition, 8(5), 530-538.

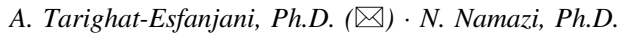
Nutrition Research Center, Nutrition Faculty, Tabriz University of Medical Sciences, Attar Nishabouri St., PO BOX 14711, 5166614711 Tabriz, Iran e-mail: tarighata@tbzmed.ac.ir; tarighata@yahoo.com

The online version of the original article can be found under doi:10.1007/s10943-014-9855-x. 